\title{
Effect of water temperature on the physiological stress and growth performance of tapah (Wallago leeri) during domestication
}

\author{
Usman Muhammad Tang, Zainal Abidin Muchlisin, Henni Syawal, Heri Masjudi
}

Received - 24 December 2016/Accepted - 16 August 2017. Published online: 30 September 2017; $\odot$ Inland Fisheries Institute in Olsztyn, Poland Citation: Tang U.M., Muchlisin Z.A., Syawal H., Masjudi H. 2017 - Effect of water temperature on the physiological stress and growth performance of tapah (Wallago leeri) during domestication - Arch. Pol. Fish. 25: 165-171.

\begin{abstract}
The objectives of the present study were to analyze the effect of temperature regimes on stress levels and to determine the suitable water temperature for the domestication of tapah, Wallago leeri Bleeker. A completely randomized method was used in this study, and three levels of water temperature were tested, namely, 27,29 , and $31^{\circ} \mathrm{C}$, in seven replicates. A total of 500 experimental fish were collected from the Kampar River, Langgam, Riau, Indonesia, and transported to the Aquaculture Laboratory, Riau University. The fish were reared in 21 tanks at stocking densities of 70-100 fish tank ${ }^{-1}$. The fish were fed rough fish three times a day at 08:00, 12:00, and 21:00 for 30 days. Blood samples were taken on days 1,14 , and 29, which were analyzed for cortisol, glucose, and plasma protein. Growth and survival rates were recorded at the end of the experiment. ANOVA showed that water temperature had a significant effect on the stress condition, growth, and survival rate of tapah. Lower blood glucose, protein, and cortisol plasma levels were recorded in fish acclimatized at $29^{\circ} \mathrm{C}$ with values of $14.44 \mathrm{mg} \mathrm{dL}^{-1}, 5.35 \mathrm{~g} \mathrm{dL}^{-1}$, and $6.90 \mathrm{mg} \mathrm{mL}^{-1}$, respectively. Additionally, higher growth performance $(32.30 \mathrm{~g})$ and survival rates $(100 \%)$ were also found in fish reared at $29^{\circ} \mathrm{C}$. It was concluded that the best water temperature for the domestication of tapah is $29^{\circ} \mathrm{C}$.
\end{abstract}

U.M. Tang [ $\left.\Xi^{\circ}\right]$, H. Syawal, H. Masjudi

Department of Aquaculture, Faculty of Fisheries and Marine

Sciences, University of Riau, Pekanbaru, Indonesia

e-mail: usman_mt@yahoo.co.id

Z.A. Muchlisin

Department of Aquaculture, Faculty of Marine and Fisheries, Syiah

Kuala University, Banda Aceh, Indonesia
Keywords: blood protein plasma, blood glucose, cortisol plasma, growth rate, survival rate

\section{Introduction}

Tapah, Wallago leeri Bleeker is a commercial freshwater fish in Riau waters, Indonesia. This species is distributed in southeast Asia from Thailand to Indonesia (Froese and Pauly 2017). Tapah is the main target of local fishermen in Riau Province, Indonesia. Intense fishing of this species over the last decade has resulted in declining wild populations of $W$. leeri (Utomo 2016). In addition, the tapah population is also threatened by habitat degradation from deforestation that is prompting increases in temperature and turbidity and leading to lowered dissolved oxygen concentrations. Studies on tapah are scarce; the previous study on this species focuses only on morphometric characteristics (Nathasya and Elvyra 2014), photoperiod, and feeding regimes (Giri et al. 2002).

The cultivation of tapah has been initiated to prevent declines in tapah populations, and it is based on collecting fingerlings from the wild. However, tapah cultivation has not been optimal, because the breeding technology is not well understood. Therefore, it is crucial to develop breeding technology. For this purpose, the availability of high-quality broodstock is

\footnotetext{
C Copyright by Stanisław Sakowicz Inland Fisheries Institute in Olsztyn.

(c) 2017 Author(s). This is an open access article licensed under the Creative Commons Attribution-NonCommercial-NoDerivs License (http://creativecommons.org/licenses/by-nc-nd/3.0/).
} 
critically important. Therefore, the domestication process is the first step in overcoming this problem (Muchlisin 2013).

The domestication of tapah has been initiated in Riau Province, Indonesia. However, this attempt has faced several obstacles, including the fact that many broodstock candidates collected from the wild died during the domestication process from stress in the new environment in ponds. Stress was caused by environmental changes (Biron and Benfey 1994) especially temperature fluctuation, dissolved oxygen deficiency, $\mathrm{pH}$, and high ammonia concentration during transport from the field to the domestication ponds (Brown 1993, Sandodden et al. 2001, Van Ham et al. 2003, Hoskonen and Pirhonen 2006, Rollo et al. 2006). Sudden temperature changes can cause difficulties in fish acclimatization that disturb physiological processes (Xafri et al. 2013) and causes cell damage and death (Affandi and Tang 2003). Changes in water temperature increase energy requirements from blood glucose for thermogenesis, which can be met if the glucose in the blood can immediately enter the target cells. The success of glucose transport to cells is specified by insulin activation and insulin-like growth factors (Fenn et al. 2016). Additionally, the role of thyroid hormone in controlling osmoregulatory and metabolic rates is crucial since osmoregulatory and metabolic rates are also affected by temperature (Peter 2011).

Studies of the effects of temperature on metabolic rates and growth performance have been conducted on several species, for example, Rhamdia quelen (Quoy \& Gaimard) (Lermen et al. 2004), Cyclopterus lumpus L. (Nytro et al. 2014), and Polyprion oxygeneios (Schneider \& Forster) (Tromp et al. 2016). In addition, Long et al. (2012) studied temperature stress responses on the development of larval zebrafish, Danio rerio (Hamilton), and they found that the development of zebrafish larvae was significantly delayed under cold stress, while heat stress also exerted an inhibitory effect, which was lower than that of cold stress. Indeed, Giri et al. (2014) studied the role of HSP70 in cytoplasm protection against thermal stress in rohu, Labeo rohita (Hamilton), and they found that the LrHSP70 gene plays an important role in response to thermal and cold stress in fish. However, there was no information on the effect of temperature regimes on the physiological performance of tapah during domestication. This information is useful when designating the optimum temperature for acclimatization during tapah domestication. Hence, the objectives of the present study were to analyze stress levels of domesticated tapah under various temperature regimes and to determine the optimum water temperature for tapah domestication.

\section{Materials and methods}

\section{Experimental design}

The experiment was conducted in the Laboratory of Aquaculture Technology, Faculty of Fisheries and Marine Sciences, University of Riau, Pekanbaru, Indonesia, from November 2014 to April 2015. A completely randomized design was used in this study. Three temperature regimes were tested, namely, 27, 29 , and $31^{\circ} \mathrm{C}$, and every treatment was conducted in seven replicates. A total of 21 aquarium tanks $(80 \mathrm{~cm}$ $\times 40 \mathrm{~cm} \times 40 \mathrm{~cm}$ ) were used, and every tank was equipped with aerator and a heater which was adjusted to the respective temperature being tested.

\section{Experimental fish collection}

A total of 500 fingerling tapah with an average weight of $45.00 \pm 3.98 \mathrm{~g}$ were collected from local fishermen at the Kampar River, Langgam Village, Riau Province, Indonesia. The fish were starved for 24 hours prior to transport to the laboratory. The fish were stocked into plastic containers $(100 \mathrm{~L})$ at a stocking density of 70-100 fingerlings, and every container was equipped with portable aerator, and then the fish were transported to the laboratory. The blood protein, glucose, and cortisol plasma levels were measured to analyze the stress condition of the experimental fish. 


\section{Acclimatization process and blood sample analysis}

The fish were distributed into experimental tanks (96 $\mathrm{L})$ at respective water temperatures. The fish were fed rough fish three times a day at 08:00, 12:00, and 21:00 at 3\% body weight for 30 days, and weight gain was measured at bi-weekly intervals. Three fish from every treatment were chosen randomly, and blood samples were collected from the caudal vein at the ventral vertebrae using a sterile syringe. The blood was placed in Eppendorf tubes, and then centrifuged at 3000 rpm for 10 minutes (Alishahi and Buchmann 2006). The blood plasma was removed and placed in new tubes and kept at $-150^{\circ} \mathrm{C}$ in a freezer prior to further analysis. The blood samples were collected three times during the study on days 1, 14, and 29.

\section{Blood plasma cortisol analysis}

Cortisol levels were examined with the radioimmunoassay (RIA) method based on Syawal et al. (2012). A total of $25 \mu \mathrm{L}$ blood plasma was taken and placed in a polypropylene tube, and $1 \mathrm{ml}$ of Coat-A-Count Cortisol reagent that contains radioactive cortisol was added to the tube, which was then centrifuged for $5 \mathrm{~min}$. The solution was incubated for $45 \mathrm{~min}$ at $37^{\circ} \mathrm{C}$. The cortisol level was calculated using a gamma counter (Anderson and Siwicki 1995).

\section{Blood plasma glucose analysis}

A total of $1000 \mu \mathrm{L}$ glucose reagents were mixed with $10 \mu \mathrm{L}$ blood plasma, the mixed solution was left for 15 min to become pink, and then the solution was transferred into a curved glass $(1.5 \mathrm{~mL})$ for spectrophotometry analysis at 546 wavelengths. A total of $10 \mu \mathrm{L}$ standard solution and $1000 \mu \mathrm{L}$ glucose reagents were mixed and used for spectrophotometry analysis at a similar wavelength for comparison. The blood glucose value was examined using the GOD-PAP Enzymatic Photometry Test (Thomas 1998).

\section{Total plasma protein analysis}

The total plasma protein was examined based on Anderson and Siwicki (1995) as follows: the blood samples were taken from the caudal fin with anticoagulant syringes rinsed in $3.8 \% \mathrm{Na}$ citrate. The blood was centrifuged at $1000 \mathrm{rpm}$ for $5 \mathrm{~min}$. A total of $5 \mu \mathrm{L}$ plasma was transferred into a microtube; then $25 \mu \mathrm{L}$ reagent $\mathrm{A}$ and $200 \mu \mathrm{L}$ reagents $\mathrm{B}$ (Bio-Rad, Hercules, CA) were added to the plasma solution and then stirred homogeneously. The mixed solution was incubated for $15 \mathrm{~min}$ at room temperature and then examined for plasma protein absorbance at wavelengths of $\lambda=595-610 \mathrm{~nm}$.

\section{Weight gain and survival rate}

The survival rate was calculated based on Muchlisin et al. $(2016)$ as follows: $\mathrm{SR}=(\mathrm{No}-\mathrm{Nt}) \times \mathrm{No}^{-1} \times 100$, where SR is the survival rate (\%), Nt is the total number of fish that died during the experiment, and No is the total number of fish at the start of the experiment. Weight gain was calculated as follows: $\mathrm{Wg}=\mathrm{Wt}-$ $\mathrm{Wo}$, where $\mathrm{Wg}$ is weight gain $(\mathrm{g})$, Wt is the average body weight of the fish at the end of the experiment (g), and Wo is the average body weight of the fish at the start of the experiment (g).

\section{Data analysis}

The data was subjected to the Analysis of Variance (ANOVA) test and followed by a comparison of means using the Duncan multiple-range test at a confidence level of 95\% (Sofyan and Werwatz 2001). All statistical analyses were performed using SPSS software ver. 13.0.

\section{Results}

The blood glucose level of the tapah before transport was $18.22 \mathrm{mg} \mathrm{dL}^{-1}$, and the blood glucose levels were increased to $33.29-43.83 \mathrm{mg} \mathrm{dL}^{-1}$ after transport from the field to the laboratory (Table 1); then the values decreased to $14.95-36.64 \mathrm{mg} \mathrm{dL}^{-1}$ after 
Table 1

Total blood glucose levels of tapah (W. leeri) before and after transport. Mean values $( \pm \mathrm{SD})$ in the same column followed by a different superscript are significantly different $(\mathrm{P}<0.05)$

\begin{tabular}{lll}
\hline \hline Transport tank no. & $\begin{array}{l}\text { Total blood glucose before transport } \\
\left(\mathrm{mg} \mathrm{dL}^{-1}\right)\end{array}$ & $\begin{array}{l}\text { Total blood glucose after transport from field to laboratory } \\
\left(\mathrm{mg} \mathrm{dL}^{-1}\right)\end{array}$ \\
\hline \hline 1 & 18.22 & 33.29 \\
2 & 18.22 & 33.29 \\
3 & 18.22 & 43.83 \\
\hline \hline
\end{tabular}

Table 2

Protein and cortisol plasma of tapah (W. leeri) acclimatized at three temperatures. Mean values $( \pm$ SD) in the same column followed by a different superscript are significantly different $(\mathrm{P}<0.05)$

\begin{tabular}{|c|c|c|c|}
\hline Acclimatization temperature & $\begin{array}{l}\text { Total blood glucose after ac- } \\
\text { climatization }\left(\mathrm{mg} \mathrm{dL}^{-1}\right)\end{array}$ & Protein plasma $\left(\mathrm{g} \mathrm{dL}^{-1}\right)$ & Cortisol plasma $\left(\mathrm{mg} \mathrm{mL}^{-1}\right)$ \\
\hline $27^{\circ} \mathrm{C}$ & $24.27 \pm 5.68^{b}$ & $4.05 \pm 0.90^{\mathrm{a}}$ & $20.32 \pm 1.84^{b}$ \\
\hline $29^{\circ} \mathrm{C}$ & $14.95 \pm 2.30^{\mathrm{a}}$ & $4.99 \pm 0.79^{\mathrm{a}}$ & $6.90 \pm 4.52^{\mathrm{a}}$ \\
\hline $31^{\circ} \mathrm{C}$ & $36.64 \pm 5.08^{\mathrm{c}}$ & $2.77 \pm 0.44^{\mathrm{b}}$ & $88.10 \pm 4.22^{\mathrm{c}}$ \\
\hline
\end{tabular}

Table 3

Weight gain and survival rates of tapah (W. leeri) in three water temperatures for 30 days of the experiment. Mean values (mean \pm $\mathrm{SD})$ in the same column followed by a different superscript are significantly different $(\mathrm{P}<0.05)$

\begin{tabular}{lll}
\hline \hline Water temperature & Average weight gain $(\mathrm{g})$ & Average survival rate $(\%)$ \\
\hline \hline $27^{\circ} \mathrm{C}$ & $26.82 \pm 5.54^{\mathrm{b}}$ & $95.83 \pm 10.20^{\mathrm{b}}$ \\
$29^{\circ} \mathrm{C}$ & $32.30 \pm 5.64^{\mathrm{c}}$ & $100.00 \pm 0.00^{\mathrm{b}}$ \\
$31^{\circ} \mathrm{C}$ & $2.95 \pm 2.61^{\mathrm{a}}$ & $66.67 \pm 12.91^{\mathrm{a}}$ \\
\hline \hline
\end{tabular}

acclimatization. Lower glucose levels were noted in fish acclimatized at $29^{\circ} \mathrm{C}$ (Table 2). The protein and cortisol plasma levels of the tapah after acclimatization ranged from 2.77 to $4.99 \mathrm{~g} \mathrm{dL}^{-1}$ and from 6.90 to $88.10 \mathrm{mg} \mathrm{mL}^{-1}$, respectively (Table 2 ). The acclimatization temperature had a significant effect on blood glucose, protein plasma, and cortisol plasma levels (ANOVA, $\mathrm{P}<0.05$ ). The lowest protein plasma level was noted at $27^{\circ} \mathrm{C}$, but this value was not significantly different from that of the protein plasma at $29^{\circ} \mathrm{C}$, while the lowest cortisol plasma was recorded at $29^{\circ} \mathrm{C}$, and this value was significantly different from the other treatments $(\mathrm{P}<0.05)$.

The average weight gain range was 2.95 to 32.30 $\mathrm{g}$, while survival rate ranged from 66.67 to $100 \%$. Water temperature had a significant impact on tapah weight gain and survival rates (ANOVA, $\mathrm{P}<0.05$ ). The Duncan multiple-range test showed that the highest weight gain was noted in the fish reared at $29^{\circ} \mathrm{C}$, and that this value was significantly different from 27 and $31^{\circ} \mathrm{C}$, while the highest survival rate was also recorded at $29^{\circ} \mathrm{C}$, but this value was not significantly different that at $27^{\circ} \mathrm{C}$ (Table 3). The results revealed that higher weight gain and survival rates were recorded in fish reared at $29^{\circ} \mathrm{C}$; the conclusion is that this is the suitable water temperature for tapah during domestication. Lower weight gain and survival rates were noted in the fish reared at $31^{\circ} \mathrm{C}$. This is probably due to stress that disrupted metabolic processes. Direct observations of the fish reared at $31^{\circ} \mathrm{C}$ showed that they were not responding to feed and passive swimming activity was detected. 


\section{Discussion}

The study revealed that temperature plays an important role in acclimatization, with increased blood glucose and cortisol plasma levels during transport that decreased after acclimatization, and the best results were noted at $29^{\circ} \mathrm{C}$. This finding concurs with the results of Kubulay and Ulukoy (2002), who report that water temperature is a crucial stress factor in rainbow trout, Oncorhynchus mykiss (Walbaum), and that higher temperature fluctuations cause acute stress in these fish.

Water temperature is an important immune system regulator in fish (Bozorgnia et al. 2011); low ambient temperatures increase pressure on fish immune systems, both specific and non-specific (Koeypudsa and Jongjareanjai 2010). Additionally, water temperature also significantly affects food intake, metabolic rates, enzyme activity, membrane function, and protein synthesis (Wedemeyer 1996); therefore, water temperature significantly affects fish growth performance as was indicated in the present study. This finding concurs with Nytro et al. (2014), who reported that the growth performance of lumpfish, C. lumpus, is affected by water temperature. A similar study has also been published on P. oxygenation (Tromp et al. 2016). Moreover, temperature stress inhibits larval development in $D$. rerio (Long et al. 2012). Water temperature also affects the activity of metabolic enzymes, for example, proteinase. These enzymes play an important role in catabolic and anabolic processes that provide fish with energy (Kuz'mina et al. 2008). According to Affandi and Tang (2003), metabolic rates increase with increases in the activity of metabolic enzymes resulting in an increase in the metabolic rate in the blood. When the metabolite level in the blood increases, fish become hungry; this stimulates the appetite and feed consumption increases. High feed intake increases the energy supply for basal maintenance and growth.

Blood glucose and cortisol levels are frequently used to assess stress in fish (Biron and Benfey 1994, Vijayan et al. 1997, Wendelaar Bonga 1997, Mommsen et al. 1999, Kucukgul and Sahan 2008, Syawal et al. 2012). The results of the present study indicate that glucose levels increased during transport from the field to the acclimatization pond. Increased blood glucose levels are also accompanied by increased blood cortisol levels. However, glucose levels declined after acclimatization, and the best levels were noted at $29^{\circ} \mathrm{C}$. High blood glucose levels can reduce appetite and inhibit growth and the reproductive development of fish (Cuban and Sen 2011). This is because energy needs are supplied by the blood glucose (Hesser 1960). In contrast, when blood glucose levels are low, the fish feel hungry and feed to meet increased energy needs. This phenomenon is crucial during weaning in the domestication process when fish have to switch from feeding on wild to domestic foods. The study showed that, at $29^{\circ} \mathrm{C}$, the blood glucose levels decreased more sharply and were closer to those of wild fish. This suggests that the ideal temperature for the acclimatization of tapah was $29^{\circ} \mathrm{C}$.

In general, the results revealed that the best protein and cortisol plasma levels were found in fish acclimatized at $29^{\circ} \mathrm{C}$. At this temperature, blood protein was the highest and cortisol plasma was the lowest compared to other treatments. The direct measurement of cortisol plasma of unstressed (normal) fish ranged from 3.23 to $10.29 \mathrm{mg} \mathrm{mL}^{-1}$, while in stressed fish it ranged from 77.36 to $135.34 \mathrm{mg}$ $\mathrm{mL}^{-1}$. This is an indication that the metabolic processes of fish run well at this temperature, because the fish utilize food effectively. Increasing blood cortisol levels causes declines in the blood plasma protein that negatively affects growth and survival rates as indicated in this study.

In addition to applying a suitable ambient temperature during acclimatization, as in the current study, the application of an active compound of raw materials in the diet also successfully reduced temperature stress and enhanced fish growth performance and survival rates. For example, Kazeem et al. (2017) used an aqueous extract of Moringa oleifera leaf in the feed to counter hyperthermal-induced stress effects on Nile tilapia, Oreochromis niloticus (L.), and they found that the survival rates of the fish were higher than in the control group. Yanti et al. (2013) and Dewi et al. (2013) used jaloh leaf, Salix tetrasperma, extract to reduce stress and enhance growth rates of Nile tilapia 
and African catfish, Clarias gariepinus (Buchell), respectively.

\section{Conclusions}

Water temperature had a significant effect on the blood protein, blood glucose plasma, blood cortisol plasma, growth performance, and survival rates of tapah. The results indicate that the best water temperature for the domestication of tapah is $29^{\circ} \mathrm{C}$.

Acknowledgements. This study was supported by the University of Riau. Therefore, the authors would like to thank the Rector of Riau University for supporting the study. Our appreciation also goes to PT Saraswanti Indo Genetech for their assistance during laboratory work.

Author contributions. U.M.T. conceptualization, design the experiment, funding acquisition and approved the final manuscript; Z.A.M. reviewed the manuscript and substantially improved quality of the paper and proofread; H.S. statistically analyzed the data, interpreted the data and wrote the first draft manuscript; H.M. investigation, data curation, data validation, and data visualization.

\section{References}

Affandi R., Tang U.M. 2003 - Animal water physiology Universitas Riau Press, Pekanbaru, Riau. 217 p. (in Indonesian).

Alishahi M., Buchmann K., 2006 - Temperature dependent protection against Ichthyophthirius multifiliis (Fouquet) following immunization of rainbow trout using live thronts - Dis. Aquat. Org. 72: 269-273.

Anderson D.P., Siwicki AK. 1995 - Basic hematology and serology for fish health program - In: Diseases in Asian aquaculture II (Eds) M. Sharif, J.R. Arthur, J.P. Subangshinghe, Fish Health Section, Asian Fisheries Society, Manila, Phillipines: 185-202.

Barton BA., Morgan JD., Vijayan MM. 2002 - Physiological and condition-related indicators of environmental stress in fish - In: Biological indicators of aquatic ecosystem stress (Ed.) S.M. Adam, American Fisheries Society, Bethesda, MD: 111-148.

Biron M., Benfey TJ. 1994 - Cortisol, glucose and haematocrit changes during acute stress, cohort sampling, and the diet cycle in diploid and triploid brook trout (Salvelinus fontinalis Mitchill) - Fish Physiol. Biochem. 13: 153-160.

Bozorgnia A, Hosseinifard M, Alimohammadi R. 2011 Acute effect of different temperature in blood parameters of common carp (Cyprinus carpio) - In: Proc. $2^{\text {nd }}$ International Conference on Environmental Science and Technology, IPCBEE, IACSIT Press, Singapore: 52-55.

Brown J.A. 1993 - Endocrine responses to environmental pollutants - In: Fish ecophysiology (Eds) J.C. Rankin, F.B. Jensen, Chapman and Hall, London: 276-297.

Cuban M.Z., Sen D. 2011 - Examination of liver and muscle glycogen and blood glucose levels of Capoeta umbla (Heckel, 1843) living in Hazar Lake and Keban Dam Lake (Elazig, Turkey) - Afr. J. Biotechnol. 10: 10271-10279.

Dewi C.D., Muchlisin Z.A., Sugito 2013 - Growth performance and survival rate of African catfish larvae (Clarias gariepinus) at different concentration of jaloh leaf powders (Salix tetrasperma Roxb) in the formulated diet Depik 2: 45-49 (in Indonesian).

Fenn C. M., Bledsoeb J.W., Smallb B.C. 2016 - Functional characterization of insulin-like growth factors in an ancestral fish species, the Shovelnose sturgeon Scaphirhynchus platorhynchus - Comp. Biochem. Physiol. A-Mol. Integr. Physiol. 199: 21-27.

Froese R., Pauly D. 2017 - FishBase - World Wide Web electronic publication. www.fishbase.org, version (06/2017).

Giri S.S., Sahoo S.K., Sahu B.B., Sahu A.K., Mohanty S.N., Mukhopadhyay P.K., Ayyappan S. 2002 - Larval survival and growth in Wallago attu (Bloch and Schneider): effects of light, photoperiod and feeding regimes Aquaculture 213: 151-161.

Giri S.S., Sen S.S., Sukumaran V. 2014 - Role of HSP70 in cytoplasm protection against thermal stress in rohu, Labeo rohita - Fish Shellfish Immunol. 41: 294-299.

Hesser E.F. 1960 - Methods for routine fish hematology Progress Fish-Cult. 22: 164-170.

Hoskonen P., Pirhonen J. 2006 - Effects of repeated handling, with or without anaesthesia, on feed intake and growth in juvenile rainbow trout, Oncorhynchus mykiss (Walbaum) - Aquac. Res. 37: 409- 415.

Kazeem G.O., Adedayo F.E., Thomas A.O. 2017 Hyperthermal-induced stress effects on survival and expression of heat shock protein (HSP) genes in Nile tilapia, Oreochromis niloticus fingerlings fed aqueous extract from Moringa oleifera leaf - Livestock Res. Rural Develop. 29: \#79.

Koeypudsa W., Jongjareanjai M. 2010 - Effect of water temperature on hematology and virulence of Aeromonas hydrophila in hybrid catfish (Clarias gariepinus Burchell) C. macrocephalus Gunther) - Thai J. Vet. Med. 40: 179-186. 
Kubulay A., Ulukoy G. 2002 - The effect of acute stress on rainbow trout (Onchorhynchus myskiss) - Turk. J. Zool. 56: 249-254.

Kucukgul A., Sahan A. 2008 - Acute stress response in common carp (Cyprinus carpio Linnaeus, 1758) of some stressing factors - J. Fish. Sci. 2: 623-631.

Kuz'mina V.V., Skvortsova E.G., Shalygin M.V. 2008 - Effect of temperature on proteinase activities in intestinal chyme and mucosa of fish of different ecological groups J. Evol. Biochem. Physiol. 44: 569-575.

Lermen C.L., Lappe R., Crestani M., Viera V.P., Gioda C.R., Schetinger M.R.C., Baldisserotto B., Moraes G., Morsch V.M. 2004 - Effect of different temperature regimes on metabolic and blood parameters of silver catfish Rhamdia quelen - Aquaculture 329: 497-507.

Long Y., Li L., Li Q., He X., Cui Z. 2012 - Transcriptomic characterization of temperature stress responses in larval zebrafish - PLOS ONE 7(5): e37209.

Mommsen T.P., Vijayan M.M., Moon T.W. 1999 - Cortisol in teleosts: dynamics, mechanisms of action, and metabolic regulation - Rev. Fish Biol. Fish. 9: 211-268.

Muchlisin Z.A. 2013 - Distributions of the endemic and threatened freshwater fish depik, Rasbora tawarensis Weber \& de Beaufort, 1916 in Lake Laut Tawar, Aceh Province, Indonesia - Songklanakarin J. Sci. Technol. 35: 483-488.

Muchlisin Z.A., Arisa A.A., Muhammadar A.A., Fadli N., Arisa I.I., Siti-Azizah M.N. 2016 - Growth performance and feed utilization of keureling (Tor tambra) fingerlings fed a formulated diet with different doses of vitamin $\mathrm{E}$ (alpha-tocopherol) - Arch. Pol. Fish. 24: 47-52.

Nathasya N., Elvyra R. 2014 - Morphometric of tapah (Wallago leeri Bleeker, 1851) from the Siak River and the Kandis River of Riau Province - J. Online Mahasiswa 1: 1-12 (in Indonesian).

Nytro A.V., Vikingstad E., Foss A., Hangstad T.A., Reynolds P., Eliassen G., Elvegard T.A., Falk-Petersen I.B., Imsland A.K. 2014 - The effect of temperature and fish size on growth of juvenile lumpfish (Cyclopterus lumpus L.) Aquaculture 434: 296-302.

Peter M.C.S. 2011 - The role of thyroid hormones in stress response of fish - Gen. Comp. Endocrinol. 172: 198-210

Rollo A., Sulpizio R., Nardi M., Silvi S., Orpianesi C., Caggiano M., Cresci A., Carnevali O. 2006 - Live feed supplement in aquaculture for improvement of stress tolerance - Fish Physiol. Biochem. 32: 167-177.

Sandodden R., Finstad B., Iversen M. 2001 - Transport stress in Atlantic salmon (Salmo salar L.): anaesthesia and recovery - Aquac. Res. 32: 87-90.

Sofyan H., Werwatz A. 2001 - Analyzing XploRe download profiles with intelligent miner - Computation Stat. 16: 465-479.

Syawal H., Kusumorini N., Manalu W., Affandi R. 2012 Respons fisiologis dan hematologis ikan mas (Cyprinus carpio) pada suhu media pemeliharaan yang berbeda - J. Iktiol. Indonesia 12 (1): 1-11.

Thomas L. 1998 - Clinical Laboratory Diagnostic, 1st Edition - TH-Books Verlagsgesellschaft, Franfurt.

Tromp J.J., Jones P.L., Symonds J.E., Walker S.P., Pope A., Pether S.M.J., Afonso L.O.B. 2016 - Effects of commercial diets and temperature on the growth performance and stress response of hapuku (Polyprion oxygeneios) Aquaculture 452: 128-133.

Utomo A.D. 2016 - Strategy of banjiran swamp forest fisheries management in Sumatra and Kalimantan - J. Kebijakan Perikanan Indoesia 8: 13-20 (in Indonesian).

Van Ham E.H., Van Anholt R.D., Kruitwagen G., Imsland A.K., Foss A., Sveinsbo B.O., Fitzgerald R., Parapoura A.C., Stefansson S.O., Bonga S.E.W. 2003 - Environment affects stress in exercised turbot - Comp. Biochem. Physiol. A-Mol. Integr. Physiol. 136: 525-538.

Vijayan M.M., Pereira C.E., Graub E.G., Iwamaa G.K. 1997 Metabolic responses associated with confinement stress in tilapia: the role of cortisol - Comp. Biochem. Physiol. C-Toxicol. Pharmacol. 116: 89-95.

Xafri M., Arafat C., Farzana S. 2013 - The causes of stress on intestinal microbiota of Atlantic salmon, Arctic charr, Atlantic cod and rainbow trout - Adv. Aquacult. Fish. Manage. 1: 034-042.

Wedemeyer G.A. 1996 - Physiology of fish in intensive culture system - Chapman and Hall, New York, 232 p.

Wendelaar Bonga S.E. 1997 - The stress response in fish Physiol. Rev. 77: 591-625.

Yanti Z., Muchlisin Z.A., Sugito 2013 - Growth performance and survival rate of tilapia larvae (Oreochromis niloticus) at different concentrations of jaloh leaf powders (Salix tetrasperma) in the formulated diet - Depik 2: 16-19 (in Indonesian). 